\title{
Livelihood Patterns of the Tibetan \\ Refugees in Kathmandu
}

$\sim$ Neelam Shahi ${ }^{1}$

\begin{abstract}
This Study entitled as "Livelihood Pattern of the Tibetan Refugees in Nepal" (A Case Study of the Samdupling in Jawalakhel and Khampa Refugee Camp in BoudhaJorpati) aims to discover the livelihood patterns of Tibetan refugees residing in the Samdupling camp in Jawalakhel and Khampa Refugee's Camp in Boudha-Jorpati. The paper intends to examine the problems confronted by Tibetan refugees residing in the Samdupling camp and Khampa Refugee's Camp. The study itself is conducted with the objectives of describing the present socio-economic status of Tibetan refugees dwelling in aforementioned camps located inside the Kathmandu valley and Lalitpur.

This write-up not only deals with different livelihood aspects of Tibetan refugees but also compares the livelihood of two camps to list out the social, economic and political problems affecting their livelihood. However, this study is mainly based on the primary information and the data which were collected using the techniques of household survey and sampling survey, along with questionnaire and interview during the several field visits to camps.

The paper concludes by stating that government intervention is required to resolve the issues affecting the livelihood of Tibetan refugees. Tibetan refugees' problems required a political yet humanitarian resolution. The government needs to decide on whether to endow the citizenship or refugee card to the refugees who have been deprived of the both, or opt for the third-party settlement. For that Tibetans refugees also need to cooperate and coordinate with the refugees department under the Ministry of the Home Affair, Government of Nepal
\end{abstract}

Keywords: Refugees, Tibetans, Livelihood, Kathmandu

\section{INTRODUCTION}

\section{Background of the Study}

What we understand by the term livelihood? The most widely used definition of livelihood is put forward by Robert Chambers and Gordon Conway. "Livelihood comprises the capabilities, assets (stores, resources, claims and access) and

1 Neelam Shahi is an IR Scholar and her areas of interest are China-U.S Trade Relations, NepalChina Trade Relations, Foreign Employment and Remittance. 
activities required for a means of living" (Chambers and Conway, (1991, p.7). Livelihood comprises of people, their capabilities and their means of living, including food, income and assets/ tangible assets are resources and stores, and intangible assets are claims and access. Livelihood is environmentally sustainable when it maintains or enhances the local and global assets on which livelihood depend, and has net beneficial effects on other livelihoods. A livelihood is socially sustainable which can coop with and recover from stress and shocks, and provide for future generations. (Conway, December 1991).

Livelihood perspectives have been central to rural development thinking and practice in the past decade. Livelihood perspectives start with how different people in different places live. Varieties of definition are offered in the literature, including, for example, "the means of gaining a living" (Chambers 1995, p.vi) or "a combination of the resources used and the activities undertaken in order to live" (Scoones, 2009).

The World Development Report 2008 of the world bank on agriculture concentrated on the significance of livelihoods, characterized by different approaches based on farming (market-oriented and subsistence), labor, migration and diversification and three different types of economy: agriculture-based, transforming and urbanized (World Bank 2007, p.76).

Attention to how livelihood is structured by relations of class, caste, gender, ethnicity, religion and cultural identity are central. Understanding of agrarian structures requires as Bernstein and others point out, asking the basic questions: who owns what, who does what, who gets what and what do they do with it? A livelihood comprises the capabilities, assets (including both material and social resources) and activities required for a means of living (Bernstein et al, 1992, p.24).

A livelihood is sustainable when it can cope with and recover from stress and shocks and maintain or enhance its capabilities and assets both now and in the future, while not undermining the natural resource base (Chambers \& Conway, 1991). In order to better understand how people develop and maintain livelihoods, the UK Department for International Development (DFID), building on the work of practitioners and academics, developed the Sustainable Livelihood Framework (SLF).

This framework is an analysis tool, useful for understanding many factors that affect a person's livelihood and how those factors interact with each other. The SLF views livelihood as systems and provides a way to understand:

1. The assets people draw upon

2. The strategies they develop to make a living

3. The context within which a livelihood is developed 
4. And those factors that make a livelihood more or less vulnerable to shocks and stresses

Talking about livelihood asset they may be tangible, such as food stores and cash savings, as well as trees, land, livestock, tools, and other resources. Assets may also be intangible such as claims one can make for food, work, and assistance as well as access to materials, information, education, health services and employment opportunities (ISDR). Another way of understanding the assets, or capitals, that people draw upon to make a living is to categorize them into the following five groups: human, social, natural, physical, financial, and political capitals.

Table 1: Livelihood Assets

\begin{tabular}{|l|l|}
\hline Human capital & Skills, knowledge, health and ability to work \\
Social capital & $\begin{array}{l}\text { Social resources, including informal networks, membership } \\
\text { of formalized groups and relationships of trust that facilitate } \\
\text { co-operation and economic opportunities }\end{array}$ \\
\hline Natural capital & $\begin{array}{l}\text { Natural resources such as land, soil, water, forests and } \\
\text { fisheries }\end{array}$ \\
\hline Physical capital & $\begin{array}{l}\text { Basic infrastructures, such as roads, water \& sanitation, } \\
\text { schools, ICT; and producer goods, including tools, livestock } \\
\text { and equipment }\end{array}$ \\
\hline Financial capital & $\begin{array}{l}\text { Financial resources including savings, credit, and income } \\
\text { from employment, trade and remittances }\end{array}$ \\
\hline
\end{tabular}

Source: Eldis - Livelihood Connect

These Livelihood are molded within social, economic and political contexts which is also known as livelihood context, Institutions, processes and policies, such as markets, social norms, and land ownership policies affect our capability to access and use assets for a satisfactory outcome. As these contexts change they create new livelihood obstacles or opportunities (International Recovery Platform, 2010) so livelihood context plays a very important role in the determining the livelihood of the people.

\section{Table 2: Livelihood Contexts}

\begin{tabular}{|l|l|}
\hline Social relations & $\begin{array}{l}\text { The way in which gender, ethnicity, culture, history, religion } \\
\text { and kinship affect the livelihood of different groups within } \\
\text { a community }\end{array}$ \\
\hline $\begin{array}{l}\text { Social and } \\
\text { political } \\
\text { organization }\end{array}$ & $\begin{array}{l}\text { Decision-making processes, civic bodies, social rules and } \\
\text { norms, democracy, leadership, power and authority, rent- } \\
\text { seeking behavior }\end{array}$ \\
\hline
\end{tabular}




\begin{tabular}{|l|l|}
\hline Governance & $\begin{array}{l}\text { The form and quality of government systems including } \\
\text { structure, power, efficiency and effectiveness, rights and } \\
\text { representation }\end{array}$ \\
\hline Service delivery & $\begin{array}{l}\text { The effectiveness and responsiveness of state and private } \\
\text { sector agencies engaged in delivery of services such as } \\
\text { education, health, water and sanitation }\end{array}$ \\
\hline $\begin{array}{l}\text { Resource access } \\
\text { institutions }\end{array}$ & $\begin{array}{l}\text { The social norms, customs and behaviors (or 'rules of the } \\
\text { game') that define people's access to resources }\end{array}$ \\
\hline $\begin{array}{l}\text { Policy and policy } \\
\text { processes }\end{array}$ & The processes by which policy and legislation is determined \\
\hline
\end{tabular}

Source: Eldis - Livelihood Connect

Including Tibetans and Bhutanese, total 38,490 refugees are living in Nepal officially recognized by the United Nations High Commissioner for Refugees (UNHCR). In the years 1959, 1960, and 1961 following the 1959 Tibetan uprising and exile of the Dalai Lama, over 20,000 Tibetans migrated to Nepal. Many refugees immigrated to India but some settle in refugees camps set up by the International Committee of the Red Cross, the Government of Nepal, the Swiss Government, Services for Technical Co-operation Switzerland, and Australian Refugees Committee (Refugees in Nepal, 2016).

Those who arrived before 1989 were issued refugee ID cards and benefited from de-facto economic integration but those who arrived after 1989 don't have any legal status, Many of these recent arrivals transit through Nepal on their way to India. Currently, there are twelve Tibetan Refugee camps in Nepal, each supervised by a representative appointed by the Central Tibetan Administration (Refugees in Nepal, 2016). These twelve camps are:

1. Choejor (Chorten \& Khampa Camp in Jorpati)

2. Delekling, Camp in Solukhumbu

3. Dorpattan, Camp in Baglung

4. Jampaling, Camp in Lodrik, Pokhara

5. Namgyeling, Camp in Chirok, Mustang

6. Paljorling, Camp in Lodrik, Pokhara

7. Phakshing\&Gyalsa Camp

8. Rasuwa, Dunche Camp

9. Samdupling, Jawalakhel Camp

10. Tashi Palkhiel, Pokhara Camp

11. Tashiling, Pokhara Camp

12. Walung Camp

This write-up aims to study only the two camps within Kathmandu and Lalitpur: Choejor (Chorten \& Khampa camp in Jorpati) and Samdupling camp in Jawalakhel 
Whereas Choejor here means the place where Boudha- Jorpati Settlement Officer have the office and Chorten meaning is Boudha. Here inside the Boudha Jorpati there are two camp one is Khampa Camp another is Gangchen Camp. These camps also known as the Tibetans settlement Camps. According to the BoudhaJorpati settlement officer Gangchen Settlement have around 137 household and every household has the Refugee Camps (RC). This settlement was established in 1980s. But I, am not including this settlement in my paper because everyone is having the RC. I am here going to deal with another settlement that is Khampa camp of Jorpati because people living here have both Citizenship and RC and this dissertation aims to find the difference and similarities between refugees who have RCs and who are deprived of it.

The expansionist policy pursued by the Chinese Maoist government from 19491959 resulted in the internal displacement of over one million Tibetan citizens. The majority of them took refuge in India. However, a considerable number of Tibetans entered Nepal. Tibetan refugees started arriving in the 1950s, but their first major inflow in Nepal occurred after the 1959 Lhasa uprising. King Mahendra of Nepal earned considerable gratitude for opening the Nepalese borders for Tibetan refugees. Asylum was granted to all Tibetans, irrespective of their social status. Refugee Camps were built along the mountain passes that linked Nepal to Tibet. This was a commendable action on King Mahendra's part, considering the threats of reprisal issued by the Chinese government (Maura 2003). The refugees were faced with a plethora of problems. There were serious food shortages, coupled with the lack of shelter and basic healthcare facilities.

In 1960, upon the request of Nepalese authority, the International Committee of the Red Cross (ICRC) established emergency relief camps. In a similar vein, the Nepalese government, with the assistance of funds donated by the Office of the United Nations High Commissioner for Refugee (UNHCR) also set up refugee shelter homes. Till the mid-1980s, the Nepalese government welcomed the Tibetan Refugees with open hands as the latter was not perceived as a threat to Nepalese diplomatic relations with China (mtholyoke.edu 2013)

In 1986, Tibet signed a treaty with China. One of the major impacts of the treaty was the restriction on the entry and transit of Tibetan Refugees into Nepal. From 1989, owing to Chinese pressure, Nepal embarked upon an even stricter border control policy (Lander, 2009) leading to more restrictions on the entry of Tibetan refugees. With the change of Nepal's policy to grant asylum to Tibetan Refugees latter subjected to a number of problems. One of the major problem is relates to the lack of documentation of refugees - thereby rejecting them the legal right to education and employment. Before 1989, Tibetan refugees were granted Refugee Cards (RC) by then Nepalese government to allow them to access basic facilities (IRIN, 2013). 
According to the Government of Nepal, Tibetans entering Nepal after 1989 do not have any legal status as refugees, nor have access to the protection of their human rights. It's being said that Nepal's policy is also being influenced variously. In 2011, China offered an economic aid to Nepal worth US\$70 million to Nepal which encourage her to pursue a tough policy towards the Tibetan exiles (Parajuli 2011), which led to the denial of their fundamental right to freedom and expression under Chinese influence. The Nepalese government imposed a ban on protests and demonstrations around Chinese embassy and visa offices in Kathmandu, citing security reasons (Asia News, 3 Feb, 2009)

On 10th March 2010, many Tibetans refugees were arrested after clashes with the police during a protest in Kathmandu, on the 59th anniversary of the Chinese invasion of Tibet (Asia News 18 March 2010). A further manifestation on right of the freedom of expression of Tibetan refugees became conspicuous when they chose not to carry out demonstrations, fearing repression by the police and the government, on the occasion of World Refugee Day on June 20, 2013 (Parajuli, 2013).

"The dilly-dallying of the Nepalese government on the burial issue of Tibetan monk Shamar Rinpoche also highlights the influence of China in contemporary Nepal politics. Nepal had denied giving permission for cremation for two weeks, leading to widespread accusations that it was following a policy of obeisance towards China" (Yahoo, 2014).

A 2014 report "Under China's Shadow: Mistreatment of Tibetans in Nepal" published by the International Rights group Human Rights Watch documents the sordid plight of the Tibetans in Nepal. The document mentions how the increasing Chinese influence in Nepal and its overarching economic deals have led Nepal to abandon the terms of a Gentleman's Agreement that it had concluded with the United Nations refugee agency and which is a critical instrument in ensuring the safe passage of Tibetans seeking to escape from China and/or reach India (Human Right Watch, 2014).

Prominent international organizations like United Nations and the European Union have taken stock of the plight of Tibetan Refugee in Nepal. The UNHCR has strongly advocated for protecting the rights of the Tibetan refugees by urging the Nepal government to grant them official documentation (United Nations, 2013).

A European Parliament resolution of $5^{\text {th }}$ April, 2011 urged Nepalese authorities to permit peaceful elections of Tibetans in exile on their territory and to safeguard standards of protection for all refugees ("Parlament Europew", 2011). 


\section{The Arrival of Tibetan Refugee in Nepal}

It was after the Dalai Lama's flight from Lhasa in March 1959, with the concurrent uprisings in Lhasa that large numbers of Tibetans of all classes began to cross the mountainous frontiers not only into India but also into the smaller Himalayan states of Nepal, Sikkim and Bhutan (Woodcock, 1970. P. 410). It was after Dalai Lama's left Lhasa in March 1959, with the concurrent uprisings in Lhasa that large numbers of Tibetans of all classes began to cross the mountainous frontiers not only into India but also into the smaller Himalayan states of Nepal, Sikkim and Bhutan (Woodcock, 1970. p.410). The flow of refugees began from1959 to till date but in very small ratio compared with the late 1959s. According to the field survey, it is clear that in 1959 Red Cross Society with the collaboration of the Nepal government established the settlements in Nepal for the refugees. Samdupling, Jawalakhel, and Khampa Refugee Camp, Boudha-Jorpati are some of them. Samdupling, Jawalakhel camp have 11 Ropani of area whereas Khampa Camp have 27 Ropani of area but in Samdupling camp more people live than the KhampaCamp. Talking about the basic amenities and sources of livelihood patterns these two settlements provide both. But in comparison to livelihood patterns of Samdupling, Jawalakhel settlement is relatively self-reliant than the Khampa Jorpati refugee settlement. These comparison is going to be dealt in this chapter besides throwing and light on the livelihood patterns of these two settlements Samdupling, Jawalakhel and Khampa Refugee Camp, BoudhaJorpati.

The Department of Home has established 58 Tibetan settlements in India, Nepal, Bhutan and the welfare and interests of these settlements are looked after by their respective representative or welfare officers. The settlements are primarily assisted by the Government of India and other voluntary aid organizations. Out of the 58 settlements, there are 39 major and minor settlements in India. 12 in Nepal and 7 in Bhutan.

\section{Tibetan Refugees in Nepal}

A relatively large number of Tibetan Refugees poured into Nepal in 1959 and in the early 1960s. Most of them entered the country through one of three checkpoints: the Mustang area in mid-northwestern Nepal; the Solu Khumbu area in the northeast, and Walung in the north-easternmost part of Nepal. These areas had lie in the traditional trade routes between Nepal and Tibet (Gombo, 1985). 
Table 3 Tibetan Refugees in Nepal

\begin{tabular}{|l|l|l|}
\hline \multicolumn{3}{|c|}{ TIBETAN SETTLEMENTS IN NEPAL } \\
\hline \multicolumn{1}{|c|}{ Agricultural Based (4) } & \multicolumn{1}{|c|}{ Handicraft based (6) } & \multicolumn{1}{c|}{ Cluster Based (2) } \\
\hline Delekling, Solukhumbu & Paljorling, Lodrik & Choejor, Boudha \\
\hline Dorpattan, Baglung & Gyegyeling, Rasuwa & Gyalsa-Phakshing \\
\hline Jampaling, Lodrik & Samdupling, Jawalakhel & \\
\hline Namgyelling, Lotserok & Tashi Palkhiel, Pokhara & \\
\hline & Tashiling, Pokhara & \\
\hline & Samphelling, Walung & \\
\hline
\end{tabular}

Source: Department of Home Central Tibetan Administration, Gangchen Kyishong.

According to Subedi "Tibetans who largely entered Nepal in 1959, are the first group" (Subedi, 2001). He further clarifies that:

"Refugees sheltering in Nepal can be grouped into two broad categories: those with Nepalese ethnic origin and those with another ethnic origin. Refugees with Nepalese Ethnic-origin include Bhutanese refugees, Burmese "refugees" and "refugees" from Northeastern India. Likewise, refugees with other ethnic origin include Tibetans, Bihari Muslims, Kashmiri and Punjabi refugees. Of all these refugee groups whereas Tibetans are widely acknowledged in the world scale" (Subedi, 2001).

According to the Subedi, the total number of the refugees staying at that time was around 15000. UNHCR estimates 20,400 Tibetan refugee populations in Nepal by the end of 1998(UNHCR Statistics, 1998). Subedi further states that about half of them were settled independently in Kathmandu whereas about half are living identifiable refugee settlements.

A large proportion has settled in relatively large settlements in the urban area of the Kathmandu Valley and Pokhara. Likewise, there are small settlements of Tibetans in places like Walung (Taplejung), Solukhumbu, Rasuwa, Mustang, Baglung, Lumbini (Kapilvastu), Dolpa and Jumla. Their numbers in most of these settlements are "between 200 to 500" (Subedi, 2001).

The International Campaign for Tibet (2011) reported that in average, between 2,500 and 3,500 Tibetans make the crossing annually, although tighter security restrictions across the Tibet Autonomous Region (TAR) and in the Tibet-Nepal border areas have caused these numbers to drop significantly since 2008. The International Campaign for Tibet (2011) reported that "The Nepali ethnic groups who populate these regions also share ethnic and many cultural and linguistic traits with their Tibetan brethren". 
They are less than $25 \%$ of Tibetans Refugee recorded in the settlements hold valid Refugee Certificates (RCs). RCs also known as Nepali identity documents that the government at one time issued to Tibetan refugees and their offspring's. After December 31, 1989, the government stopped accepting new Tibetan refugees and therefore issuing RCs to them, following a diplomatic rapprochement with China (Human Right Watch, 2014).

According to the Human Right Watch (2014) till 1990, it continued to issue RCs to children born in Nepal to Tibetan parents holding RCs once they turned 16. From 1994 to 1998, it gradually stopped issuing RCs altogether even for children born before 1990. Where RC serves as an official identity document and grants its holder the right to reside and travel in Nepal (with the exception of some areas). But it does not allow its owner to a wide range of rights, including property ownership, employment, higher education, and travel abroad (Human Right Watch, 2014).

Some of them have possessed citizenship which they attained through naturalization or as a result of marriage to a male Nepali citizen; some grew up in India, moved to Nepal for family reasons or employment, but have retained Indian identity papers; some still hold the nationality or passport of another country and are legal foreign residents (Human Right Watch, 2014).

\subsection{Nepalese Government Policies Concerning Tibetans Refugees in Nepal}

According to the ICT (2011) report because of the centuries-old relations between Nepal and Tibet, the Tibetans who took refuge in Nepal in the late 1950s found themselves greeted and were able to live throughout Nepal in relative freedom. This began to change in 1989 when the Nepal government changed its policy and stopped allowing the Tibetan refugees.

With this effect, a Gentleman's Agreement was established between the UNHCR and the Nepal government which stated the latter's commitment to allowing Tibetans safe passage through Nepali territory and onward to India. Tibetan refugees who had settled in Nepal before 1989 and were recognized by their official government which issued Refugee Cards which allowed the bearers the right to stay and have freedom of movement inside Nepal (ICT, 2011).

The "Gentleman's Agreement" was established between Nepal and UNHCR guaranteeing the "safe passage" of refugees from Tibet to India. The agreement states that Tibetan refugees apprehended by the Nepali authorities be handed over to UNHCR for processing and transit to Dharamsala. China rejects the categorization of Tibetans who have fled Tibet as "refugees." (Human Right Watch, 2014 p. 8). 
So those who came to Nepal before 1989 are having the refugee's card and those who came after 1989 don't have any identification card according to this report, so what are the situations and causes for those who have or have not the refugee's card to stay in Nepal for a long time. According to the ICT (2011) report the indicators for the long-staying Tibetan Refugees in Nepal are as follows:-

1. Legal status - Tibetans who had escaped from Tibet into Nepal before1989 were able to legally live in Nepal, enjoying many of the rights of citizens. It was later changed by the Government of the Nepal, which stop refugees from entering Nepal after 1989. As a non-signatory of the 1951 Refugee Convention or its 1967 Protocol, but as a state, Nepal is bound by law to respect the principle of renouncement or forcible repatriation.

2. Refugee Cards - "In 1974, the Nepal government began issuing Tibetans Refugee Identity Cards (RC), a state-recognized document which allows the holder to reside and have freedom of movement within unrestricted areas of Nepal" (ICT, 2011). This report further states that Tibetans were eligible for the RC if they or their parents entered Nepal before 1990 and once they were 16-years old. They were obligated to renew their identity card with local Nepali authorities annually. After 1989, the RC document served to distinguish between those Tibetans who were allowed to remain in Nepal and those who were obliged to pass through Nepali territory onward to India. In 1994, the Nepal government stopped issuing and renewing RCs to eligible Tibetans (ICT, 2011).

This is how inside page of the RC look like.

\section{Refugee Cards}

$\mathrm{Mr} / \mathrm{Ms} \_$is a Tibetan refugee. He/she is permitted to stay in Nepal in accordance with laws and regulations. He/she will enjoy freedom of movement within the territory of Nepal, with the exception of areas forbidden to foreigners, unless his/her habitual residence is located in such an area.

3. Citizenship-In some cases, there are some Tibetans living in Nepal who have one of the two forms of Nepali Citizenship known as Nagrikta and Angrikta. Whereas Angrikta is a form of citizenship that was given to the Tibetan guerrilla fighters after they were forced to lay down their arms in Nepal in 1974. King Mahendra decided to formalize the status of Tibetan guerrilla fighters who settled in Nepal, and some 1,500 Tibetans were given citizenship. Thereafter, their offspring would be born as Nepali citizens. In the late 1970s, the Nepal government rolled out a program to give citizenship (Nepali: Nagrikta) to hundreds of thousands of inhabitants of the Himalayan region - including Sherpas, Tamangs and Dolpas - who 
had been politically marginalized. The many Tibetans who had established homes in these areas outside of the Tibetan refugee settlements (and share a common ethnicity with these groups) were able to claim citizenship at their local government offices because they were not required to show any ID in order to do so (ICT, 2011).

4. Health and Elderly care- According to the ICT (2011), Tibetans living in Nepal can be treated at any hospital, regardless of whether they have RCs, and those who live near Pokhara and Kathmandu have easy access. However, Tibetans in the remote Himalayan settlements face challenges when in need of hospitalization. Each of the remote Himalayan settlements has a clinic that can deliver basic care, but they are not always staffed by health professionals. According to a leader of Geygeyling Tibetan settlement in Rasuwa, women can face hardship and complications during childbirth (ICT, 2011, p. 63).

5. Property rights - "Tibetans without Nagrikta, even those with RCs, are not allowed to own property in Nepal. This extends to many forms of property, including houses, offices, cars and land" (ICT, 2011).

6. Education - The majority of Tibetan families struggle to send their children to schools with a curriculum which includes the Tibetan language. Since the beginning of the Tibetan refugee crisis in the early 1960s, the provision of education has been a priority of the Tibetan exile government. Schools - both monastic and lay - were set up to cater predominantly to Tibetan children born in exile and those who every year continued to make the perilous journey out of Tibet. The 13 Tibetan schools in Nepal are operated by the Snow Lion Foundation, an NGO established in 1972 by the Swiss Development Cooperation, in cooperation with the Department of Education of the Tibetan exile government (ICT, 2011).

Tibetan refugee children were still entitled to attend schools but were no longer able to study a specifically 'Tibetan' education. Most families who could afford to choose at this juncture to send their children to Tibetan boarding schools in India. This established a pattern of cross-border migration for education which continues today and is in part why the ability to cross the Nepal-India border is so crucial for Tibetans. Although the Nepal government reversed this policy change in 1981, not all of the Tibetan refugee communities were then able to sustain their schools. The Settlement Officer at the Shabru-Besi Tibetan settlement had the following to say to ICT:

Tibetan high schools exist only in Pokhara and Kathmandu, so children from Tibetan settlements outside these areas must leave their families and live in hostels run by the high schools. Many Tibetans choose at this juncture to send 
their children to Tibetan schools in India, which many perceive as providing a better education (ICT, 2011).

Tibetan settlement was built on the land of the Nepal Red Cross and Tibetans who live outside of the settlement lived in the rented house of Nepali citizens."Those Tibetans who wish to have the security of a home or a business property, can only do so through personal arrangements with Nagrikta-holding" (ICT, 2011. P. 64)

With the different viewpoint Mathur (2014) states that Nepal government has negotiated the status of Tibetan refugees for Chinese humanitarian aid as well as military assistance -The problems are further aggravated by the fact that Nepal is not a signatory to the 1951 Refugee Convention of the UN, which explicitly states the rights of refugees and issues guidelines, laws, and convention to ensure their fair treatment (Mathur, 2014).

The current scenario of Tibetan Refugees in Nepal due to increasing Chinese pressure has implications for India too - To ensure the protection of human rights of the Tibetan refugees in Nepal, India, along with the United Nations, and the European Union must exert pressure on Nepal to sign the 1951 Refugee Convention. Active intervention by India is a necessary measure if the problems of Tibetan refugees are to be addressed effectively (Mathur, 2014).

\subsection{The Adaptation of Tibetan Refugees in the Kathmandu Valley}

According to the Gombo (1985) in his study he states that in the initial stages of their exile the Tibetan refugees of the Kathmandu Valley found themselves in a condition in which they could have farming or non-farming occupations. In starting both farming and handicraft production were encouraged by Nepalese Government. He further states that with the later the handicraft industry gradually took hold, and as the exiles became more and more familiar with the fast-growing tourist industry and general market economy of the Kathmandu Valley."They chose to concentrate on non-agricultural activities because, as an often-repeated expression used by respondents has it, "the path to eating is shorter with skills or business intelligence"(Gombo, 1985).

They have no direct productive relationship to natural resources, and consequently, their specific adaptive strategies, have been the utilization of socio-economic and cultural resources. These have shaped the development of new social organizations, and fostered both change and continuity in traditional cultural and ideological patterns (Gombo, 1985).

While talking about the socio-cultural continuity, Gombo (1985) classifies five sociocultural "resources" exist that are as follows:-

1. The retention of the traditional forms of family structure (with an even higher frequency of polygyny in the Kathmandu Valley)

2. The revival of monasticism

3. The increase in mutual-aid associations based on intra-ethnic group 
affiliation (and the subsequent resurgence of regionalism)

4. The persistence of extreme conservatism in beliefs, values, and attitudes, etc., among certain segments of the population and

5. The general devotion to Buddhism (even by the modern-educates).

All of these examples of socio-cultural resources have proved beneficial to the exiles as a whole or to different sections of the population in understanding their instantaneous socio-economic goals and in attempting to realize ideological/ political ones. Therefore these must also be viewed as adaptive strategies available to the Tibetans Refugees (Gombo, 1985).

With Similar view Woodcock (1970. P.419) states that in Nepal there is no such outlook, owing to the strange difficulties in the country. Some of the Tibetans refugees in the vicinity of Kathmandu have been structured by Swiss relief workers into self-sustaining handicraft groups, and these have a standard of living not lower than that of the local Newari farmers.

"There are also successful farming and handicrafts settlements at Pokhara and two other places in southern Nepal" (Woodcock, 1970. P. 419).

\subsection{Conceptual Framework}

In this research, the conceptual framework assumes to explain the livelihood patterns of the Tibetans Refugees as influenced by the economic status, social status and the demographic status. The livelihood pattern of the Tibetans Refugees is influenced by the economic variable that is occupations, asocial variable that is Gender, cultural and demographic variables like age structure and family size married or not.

Based on the objective of the study and available literature this study has proposed the following conceptual framework.

Independent Variables Intermediate Variables Dependent Variables

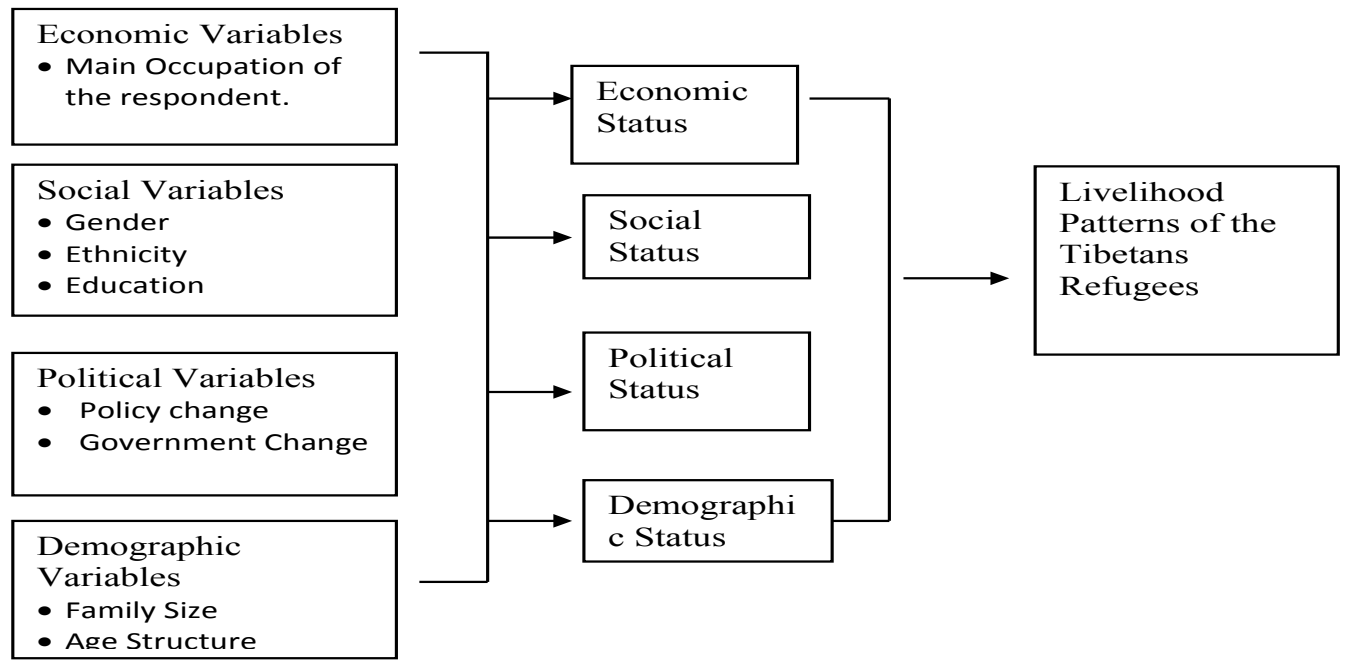


According to the Department of Central Tibetan Administration (CTA), each Tibetan settlement has a settlement officer who is appointed by Central Tibetan Administration (CTA), Dharamshala. Settlement Officer is the principal post of the settlement. He is charged with overall control of running of affairs in the settlement. The daily task for the representative range from adjudicating disputes to communicating with group leaders and outside authorities, and generally watching over the running of all aspects of the settlement.

Table 8: Livelihood Asset of People Living in the Khampa Refugee Camp.

\begin{tabular}{|l|l|}
\hline $\begin{array}{l}\text { Human capital } \\
\text { Skills, }\end{array}$ & $\begin{array}{l}\text { Every member of the family living inside the Jorpati camp } \\
\text { working. Some of the senior citizens are now retired. They } \\
\text { don't have any pension system. Their livelihood depends on } \\
\text { the saving they made while working. }\end{array}$ \\
\hline $\begin{array}{l}\text { Social capital } \\
\text { Bonding } \\
\text { Bridging linking }\end{array}$ & $\begin{array}{l}\text { All the Tibetans Refugees follow Buddhism. They have } \\
\text { a strong bonding with each other. Some of the Tibetan } \\
\text { Refugees who have Refugee Card can travel to India which } \\
\text { is playing a role of the bridging two country, bridging also } \\
\text { in a sense that their children can go to the Dharamshala of } \\
\text { India. According to the survey, it has been found that one } \\
\text { member of a family living in the settlements have Gmail } \\
\text { account and Face book account, which help them to link to } \\
\text { the people of different settlement. }\end{array}$ \\
\hline Natural capital & $\begin{array}{l}\text { As Tibetan Refugee they have been given land and rooms } \\
\text { for living, where a shortage of drinking water is a problem } \\
\text { faced by people living inside the settlement. }\end{array}$ \\
\hline Physical capital & $\begin{array}{l}\text { With the primary health center, primary school and } \\
\text { monastery Jorpati settlement provides health and educations } \\
\text { facilities to its people. This camp has 1 public toilet which } \\
\text { means sanitation is not goodin comparison to their health } \\
\text { facilities. }\end{array}$ \\
\hline Financial capital & $\begin{array}{l}\text { According to the survey, very few people have a bank } \\
\text { account and savings. Some get remittance from their } \\
\text { children who are working outside the country. }\end{array}$ \\
\hline
\end{tabular}

Source: Field survey, 2017.

This Table 8 clearly shows that people living inside Khampa camp have house (they have been given two rooms for living), clinic, monastery, park and one public toilet which are actually not sufficient for the 124 people living inside the camp, which cause directly effect on their livelihood patterns in terms of sanitations. Lack of drinking water is also the major problem of the people, though they have been given the room for living and basic facilities like health center and the 
school for their children but lack of job in the market for them is a big problem faced by the Tibetan Refugees. Some after having finishing their education go abroad for job and for living which leads to the decline of the populations living inside this camp. Some of their children are studying in India and they sometime visit them once or twice a year. Those who have citizenship it easy to them to visit their children but who don't have the citizenship it's very difficult to them to visit their children because they have to make travel document which can take 10- 15 days. They also face problem in the border areas and sometime obliged to give bribe to the army personal of both side as they demand.

Fact About the Khampa Camp Jorpati

According to the settlement officer Kalsang Dhundup, Khampa camp has 27 Ropani of land and it was established in 2034 B.S. and office of the settlement established on 2004. The population of the settlement is 124 comprising of different age group from young to old; In this camp they have been given living room. He said almost $90 \%$ of the population have citizenship and 10\% have the RC. He further stated that in every year's on April C.D.O officer come to the office for renewing of the $\mathrm{RC}$. This is the only facility we receive from the Nepalese government.

Whereas American Embassy insists of taking the refugees to whom Nepali Government doesn't issue the RC. Nepalese Government doesn't allow because of the Chinese government pressure.

\subsection{Livelihood Assets in Both Camps}

Assets play very important role in the determination of the livelihood patterns in any field. Without knowing the livelihood assets it is very difficult to determine the livelihood patterns so here is the summary of the livelihood assets in terms of human capital skills, social capital, natural capital, physical capital, finance capital and health facility and co-operative society.

i. Human capital skills, knowledge, health and ability to work: Compared to the Khampa Refugee camp, Jawalakhel camp has more human capital based on knowledge, health, and ability to work. The populations of this settlement are also more than the population in the Khampa Refugee camp. Some refugee of the Jawalakhel camp have their own restaurant and some of them are famous in the locality for the laphing (Tibetan food) they sell.

ii. Social capital in the sense of Bonding, Bridging and Linkage: As a Tibetans Refugees are Buddhist. They have a strong bonding with each other. Some of the Tibetans Refugees who have Refugees Card can travel to India. Their children can go to the Dharamshala of India. During the survey, I found that many members of a family living in the settlements have Gmail 
account and Facebook account, which help them to link to the people of different settlement.

iii. Natural capital: As a Tibetan Refugees, they have been given land and rooms for living. Shortage of drinking water is a problem faced by people living in the settlement.

iv. Financial capital including savings: In Samdupling Jawalakhel camp very few people have savings and bank accounts because they don't have citizenship card. During the survey it was found that, only one family have citizenship because she was married to a Nepali man. In Khampa camp also very less people have bank account instead of citizenship. They don't have much saving which lead to discouragement in opening bank account. They prefer to save money in local Finance like Lali Guras.

v. Health Facility: In the Samdupling Jawalakhel camp doctors from nearby town visit the settlement weekly and in Khampa camp they have their own clinic and hospital outside the camp.

vi. Co-operative Society: The settlement has a Multipurpose Co-operative Society which provides necessary services to the people inside the settlement. This society runs different section to fulfill the needs of the settlement (Only in Samdupling Jawalakhel Camp)

1. Carpet Center

2. General store section

3. Carpet washing

\subsection{The Problem Faced by the Refugees Living in Both Camps.}

The common problem faced by two camps were as follows

- The drinking water problem

- No identification so, faced problem outside the camp while traveling

- Sanitation problem

- Money not enough

- Health Problem

- Old age problem. Since old people who don't have citizenship still work for living.

- Road inside the camp is not good (Jawalakhel Camp)

- We are not allowed to celebrate of Dalai Lama Birthday (Both Camp)

- We are born here but we don't have citizenship card (Both Camp)

- Earlier we were allowed to obtain license through RC but now we can't because the government changed the policy.

- We faced problem while traveling to the India. 
- Some old people have health problem

- One household have its own problem of differently-abled child.

- No job after education.

Table 13 Comparison between Samdupling Jawalakhel, and Khampa Refugee's Camps.

\begin{tabular}{|c|c|c|}
\hline & Jorpati Camp & Jawalakhel Camp \\
\hline Established & $\begin{array}{l}\text { According to the Jorpati } \\
\text { settlement officer it was } \\
\text { established in } 1977 \text { (2034 } \\
\text { B.S) and office was } \\
\text { established in 2004. }\end{array}$ & $\begin{array}{l}\text { In1960 with the help of } \\
\text { International Red Cross } \\
\text { and Swiss Confederation } \\
\text { in Co-operation with } \\
\text { H.M.G Nepal. }\end{array}$ \\
\hline Premises & $\begin{array}{l}\text { Jorpati Premises of the camp } \\
\text { fenced by the concrete wall. }\end{array}$ & $\begin{array}{l}\text { Whereas Premises of } \\
\text { Jawalakhel is quite open. }\end{array}$ \\
\hline Area & 27 Ropani & 11 Ropani \\
\hline House & $\begin{array}{l}\text { Houses of the Jorpati } \\
\text { refugee's camp are made of } \\
\text { concrete where most of the } \\
\text { family have two rooms. One } \\
\text { for kitchen one forliving. }\end{array}$ & $\begin{array}{l}\text { Houses of the Jawalakhel } \\
\text { camps are also concrete in } \\
\text { nature. With same living } \\
\text { structure two rooms for } \\
\text { one family. }\end{array}$ \\
\hline Sanitation & Public Toilet & Public toilet \\
\hline Nearby market & Boudha, Jorpati & Patan, Jawalakhel \\
\hline Health Center & $\begin{array}{l}\text { They have their own health } \\
\text { center inside the premises } \\
\text { and also one in Jorpati in the } \\
\text { name of Tibetan Medical and } \\
\text { Astrology (p.) Ltd }\end{array}$ & $\begin{array}{l}\text { No health center Inside } \\
\text { the camp, every week } \\
\text { a local doctor visit the } \\
\text { camp. }\end{array}$ \\
\hline Park & There is one & There is one \\
\hline Security Personal & Yes & No \\
\hline Drinking water & Facing problem & Facing problem \\
\hline Population & 124 & 600 \\
\hline Refugees Card & $\begin{array}{l}90 \% \text { of the Khampa camp } \\
\text { have Citizenship. }\end{array}$ & $\begin{array}{l}\text { Some have RC some have } \\
\text { Citizenship card and some } \\
\text { do not have any card. }\end{array}$ \\
\hline
\end{tabular}

Source: Field Survey, 2017

This Table clearly shows that in almost 57 years since the establishment of the Jawalakhel camp and the population of these camp is getting lesser day by day because of the settlement of the refugees in the third Countries by the Help of host Government. Whereas the population in Samdupling Jawalakhel camp is 
more than the Jorpati Khampa camp despite of the less area. According to the settlement officer of Samdupling Jawalakhel camp"this camp have 11 Ropani of area. Whereas Jorpati Khampa Camp have 27 Ropani of the area". According to the Settlement Officer of Boudha Jorpati almost $90 \%$ of the people living inside the Khampa camp have the citizenship where $10 \%$ of themdon'thave citizen but RC whereas only $65.22 \%$ of Samdupling Jawalakhel camp refugee have $\mathrm{RC}$ whereas their children don't have anything. Only one family has citizenship because she has married a Nepali man and others have nothing. It shows that the life of the Khampa camp people is secure in terms of the Jawalakhel camp people. Most of the Khampa camp people don't have any restriction while traveling whereas as refugees in Samdupling camp people have to face difficulty for the same.

Talking about the health facilities in both the camp. Jawalakhel camp doesn't have any clinic and hospital. They visit nearby hospital. Doctor visit once a weak. Whereas Khampa Camp has its own clinic inside and hospital outside of the camp which is situated in the Boudha- Jorpati which is also an office of the settlement officer. Old/ senior people of the Jawalakhel camp still work in the carpet factory because they don't have any other option for living as they have $\mathrm{RC}$ not the citizenship which doesn't give them old age pension whereas in Khampa camp old/senior people after getting retired from their respective job they get pension from government of Nepal. This show that old age people of Jawalakhel camp have to suffer in their old age whereas Khampa camp old aged people can have relatively better time with their family. Drinking water problem is faced by the both camps.

\section{Major Findings}

- Following are some of the key finding of this research:

- Nepal has not ratified the 1951 UN Refugee Convention or its 1967 Protocol exposes but Nepal has been really welcoming to Tibetans Refugees.

- Samdupling, Jawalakhel Camp have 11 Ropani Area, whereas Jorpati has 27 Ropani Area.

- Samdupling, Jawalakhel camp has 600 populations whereas Khampa refugee's camp has 124 population.

- Samdupling Jawalakhel Camp is the oldest than the Khampa camp of the Jorpati.

- It is found that $56.55 \%$ of total population of Samdupling, Jawalakhel are engaged in the carpet factory than $13.04 \%$ engaged in the shop inside the 
carpet factory and same $13.04 \%$ of the populations have its own restaurant.

- It is found that $60 \%$ of the total household populations of Khampa refugees are engaged in the carpet industry followed by the tailoring and small cottage firm which each contributes to $30 \%$ and 10 percentage tailoring of the prayer flag.

- Every child of the Tibetans refugees goes to school.

- Both camp have school and playground facilities.

- Samdupling, Jawalakhel camp doesn't have a hospital, but has the doctor facility who visit camp once a week. Whereas Jorpati camp have its own clinic and hospital.

- Refugees in both the camps have everyday household goods such as television and fridge while some have fridge inside the house

- These two camp refugees have the social capital which is Bonding, Bridging and linking with other refugee's area in India and Nepal(See page number 38).

- In Samdupling Jawalakhel camp people have been providing room for living for which they don't have to pay if one of the family members is working in the carpet industry. Whereas in Khampa camp (Jorpati) they have been given free of cost because $90 \%$ of them have citizenship according to the settlement officer.

- Household size between 5 to 7 covers $55.56 \%$ of the populations of Samdupling Jawalakhel Camp followed by Household Size of 3 to 4 which covers $33.33 \%$ and household size 1 to 2 covers $11.11 \%$ of the populations.

- Whereas every household of Samdupling Jawalakhel camp and Khampa, Jorpati camp has an electronic device like T.V, Fridge.

- $52.17 \%$ of the sampled populations has a vehicle like a motorcycle and scooter and 13.04 has their own restaurant inside the Jawalakhel camp.

- Both camps face similar problem in day to day activities that are drinking water problem, sanitation problem, old age peoples face health problem, those who don't have citizenship card, they face problem while traveling to the India.

- Jawalakhel camp have more human capital based on knowledge and ability to work.

- Jawalakhel Tibetan Camp has its own Handicraft Center which gives employment to 150 people. 
- $65.22 \%$ of the population have the Refugee Card (RC) which is an identification document. It helps them in traveling (Samdupling Jawalakhel camp).

- Where $30.43 \%$ of the population are deprived of citizenship and RC. They find themselves in a difficult condition while traveling because of not have $\mathrm{RC}$ lead to the restriction of traveling to India and any other Countries (Samdupling Jawalakhel Camp).

- $4.35 \%$ of the population reside inside the camp who have citizenship; they get it by marrying the Male Nepali citizenship (Samdupling Jawalakhel Camp).

- $90 \%$ of the population have their citizenship which according to the survey they obtain during the panchayat regime of King Mahendra and during the rule of King Birendra before 1990s, those who have the citizenship can work anywhere in Nepal ( Jorpati Khampa Camp)

- $10 \%$ of the population don't have citizenship but RC and it is the only identification document for them (Jorpati Camp).

- Some of the children are studying in the India from both the Camp.

- Samdupling Jawalakhel camp has recreation center which offers recreational activities includes in-door games like snooker and pool.

- Jawalakhel Handicraft Center collapsed due to the earthquake on 25 April 2015, but it has still not been constructed due to insufficient capital.

- There is lack of coordination between camps and refugee department under MOHA (Ministry of Home Affair)

- Tibetan Refugees don't come to refugee department to lodge their livelihood problems.

\section{Conclusion}

The study shows that the livelihood patterns of the Tibetans refugees living in these camps is sustained through their engagement in different activities. They have endeavored to sustain their livelihood by different means: by working in carpet industry or have their own restaurant inside the camp, or even by doing work outside the camp in small cottage industries.

It is found that individual earning is not sufficient for the sustenance of livelihood, hence, it obliges almost all the mature and competent members of the same family to sell their labor.

Regarding livelihood, shelter is not a problem for them, however, as they get 
free of cost room inside the camp, particularly to those who work for the carpet industry inside the camp. Tibetans of the Khampa camp are getting free of cost room for the dwelling purpose.

Even winning bread is also not a severe plight from them since, as per the communication and discussion with them during field visits, they earn well to buy the food items of their necessities. Still, they have been facing the problem of drinking water like every communities in Kathmandu do face because of the scarcity of water.

During the field visits or even during the communication phase with Tibetan refugees, no information about the occurrence of any criminal activities inside the camps was given and when inquired about such, the answer was always no. Hence, owing to the same, it can be inferred that both the camps--Samdupling Jawalakhel camp and Jorpati camp-- are deprived of the undertakings of criminal activities, resulting into better livelihood as they were safe from any sort of burglary, theft, house-break, and other sort of crimes.

\section{Recommendations:}

\section{1) Policy Level}

- To deal with the both the prospects and challenges brought about by the issues revolving around Tibetans refugees, the country needs a rationally-designed and improved institutional framework.

- To find out best policy options to address the problem of the Refugees.

- Effective monitoring and evaluation of the Tibetans refugee problems should be done on a regular basis.

\section{2) Recommendations to Respective Bodies}

- Nepal government needs to think about the legal status of those who are deprived of their refugee card and citizenship cards. Meanwhile Tibetans Refugees also need to coordinate with local bodies.

- Government should provide special economic allowances to the senior refugees who don't have citizenship and RC. However, those refugees who have citizenship cards are getting elderly allowances and also cast voters in election.

- Nepal should deal with Tibetan refugee by not damaging her bilateral relations with China. It should be resolved in close coordination with China.

- If Government fails to address the plight of Tibetans Refugees associated with livelihood then it should pave a way for the third country settlement. 
- International organizations dealing with refugees could be negotiated by Nepal Government to improve their livelihood status but that needs to be done by clearly informing to China that it is not political but a social issue

- Cooperate fully with the Office of the United Nations High Commissioner for Refugees (UNHCR) to facilitate its mandate to protect refugees, asylum seekers, and stateless persons; once again it should be done in coordination with china.

- Establish and maintain a strong and effective working relationship with UNHCR, including by having UNHCR trained relevant officials and allowing UNHCR to resume systematic border monitoring visits

- Immediately provide all eligible Tibetans with refugee identification certificates ( $\mathrm{RCs}$ ).

- Ensure freedom of movement without discrimination but confirming it to the national security having agreed upon under the bilateral relationship between Nepal and China.

- Encourage and provide assistance to the Nepali government in creating an information sheet for distribution to all border police and immigration patrols explaining their obligations under the Gentleman's Agreement.

- Tibetans Refugees living in Kathmandu and other area of Nepal should strictly follow the Nepal law and international law. Any action against the law is punishable.

- The Nepal government should issue long-staying Tibetans, who have settled in Nepal before 1989 and their offspring, official documentation that guarantees their right to live, work and study in Nepal, and allows their travel outside of Nepal.

- Settlement Officer should coordinate and cooperate with the Ministry of the home affairs (MOHA) Government of the Nepal.

- There should be more interaction between Settlement officer and MOHA for the resolving issue of the Tibetans Refugees.

\section{References}

AsiaNews. (18 March 2010). Tibetans Jailed for Anti-Chinese Protests Go on Hunger Strike. Retrieved From http://www.asianews.it/news-en/Tibetans-jailed-for-antiChinese-protests-go-on-hunger-strike-17918.html.

AsiaNews. (3 February, 2009). Anyone Protesting against China in Kathmandu to Be Arrested. Retrieved from http://www.asianews.it/news-en/Anyone- protestingagainst-China-in-Kathmandu-to-be-arrested-14613.html. 
Baskota, Suman. (2012). Statistical Methods for Rural Development. Kathmandu, New Hira Books Enterprises

Conway, R. C. (December 1991). Sustainable rural livelihoods: practical concepts for the 21st century. IDS Discussion Paper 296, 5-6.

Gombo, Ugen. (August 1985). Tibetan Refugees in the Kathmandu Valley: A study in Socio-Culture Change and Continuity and the adaptation of a Population in Exile. Doctoral diss. State University of New York, New York.

Human Right Watch (2014). Under China's Shadow: Mistreatment of Tibetans in Nepal.

Human Rights Watch. (1 April 2014). Under China's Shadow: Mistreatment of Tibetans in Nepal. Human Rights Watch. Retrieved From URL: http://www. hrw.org/reports/2014/04/01/under-china-s-shadow-0.

InternationalRecoveryPlatform.(2010)GuidanceNoteon RecoveryLivelihoodRetrieved from http://www.unisdr.org/files/16771_16771guidancenoteonrecoveryliveliho. $\mathrm{pd} \mathrm{f}$

IRIN. (4 June 2013). Tibetan Refugees in Nepal Crying out for Documentation Retrieved from http://www.irinnews.org/report/98158/tibetan-refugees-in-nepal-cryingout-for-documentation.

Lander, John. (2009). Tibetan Refugees in Nepal. Retrieved from h t t p : / w w w . demotix.com/news/128198/tibetan-refugees-nepal

Mathur, Pawan. (13 September, 2014). Tibetan Refugees in Nepal. Tibetan Review Retrieved from http://www.tibetanreview.net/tibetan-refugees-in-nepal/

Maura, Moynihan. (2003).Tibetan Refugees in Nepal. In Bernstroff Dagmar and Hubertus von Welck (eds.) Exile as Challenge: The Tibetan Diaspora, Orient Blackswan; pp.312-314.

mtholyoke.edu (2013). Tibetan Refugees in Nepal. Retrieved from h t t p : / / w w w . mtholyoke.edu/ $\sim$ shres20u/classweb/tibetan_refugee.html.

Parajuli, Kalpit (21 June, 2013). Persecuted and Without Rights, Tibetan Refugees in Nepal Appeal. Retrieved From http://www.asianews.it/news-en/Persecuted-andwithout-rights,-Tibetan-refugees-in-Nepal-appeal-28270.html.

Parajuli, Kalpit. (19 August, 2011). Kathmandu Trades Tibetan Lives for Beijing's Money. Retrieved from http://www.asianews.it/news-en/Kathmandu-tradesTibetan-lives-for-Beijing\%E2\%80\%99s-money-22403.html

Parlament Ewropew. (2011). Retrieved March 21, 2017 from http://www. europarl.europa.eu/sides/getDoc.do?type=MOTION\&reference=B7-20110266\&language $=\mathrm{MT}$ 
Refugees in Nepal. (December 2016) in Wikipedia. Retrieved from https://en.wikipedia. org/wiki/Refugees_in_Nepal

Subedi, Bhim. (2001). The Problem of Bhutanese Refugees and Comparison with the Tibetan Refugees in Nepal. Retrieved From http://himalaya.socanth.cam.ac.uk/ collections/journals/contributions/pdf/CNAS_28_01_05.pdf

The International Campaign for Tibet. (2011). Dangerous Crossing: Conditions Impacting the fight of Tibetan Refugees. Washington, DC

United Nations. (2013). United Nations High Commissioner for Refugees, United Nations Nepal Information Platform. Retrieved From URL: http://un.org.np/ unher.

Wong, Edward. (13 April, 2013). China Makes Inroads in Nepal, and Stanches Tibetan Influx. The New York Times. Retrieved From http://www.nytimes. com/2013/04/14/world/asia/china-makes-inroads-in- nepal-stemming-tibetanpresence.html?pagewanted $=$ all\&_r $=0$.

Woodcock, George. (Autumn, 1970). Tibetan Refugees in a Decade of Exile. University of the British Columbia, Pacific Affairs Vol.43, No.3, pp. 410-420

Yahoo (2014). Tibetan monk cremated in Nepal despite China controversy. Retrieved From https://uk.news.yahoo.com/tibetan-monk-cremated-nepal-despite-chinacontroversy-112018577.html\#u8ALif7. 